\title{
Visualization of 'Candidatus Liberibacter asiaticus' Cells in the Vascular Bundle of Citrus Seed Coats with Fluorescence In Situ Hybridization and Transmission Electron Microscopy
}

\author{
Mark E. Hilf, Kenneth R. Sims, Svetlana Y. Folimonova, and Diann S. Achor
}

First and second authors: United States Department of Agriculture-Agricultural Research Service, United States Horticultural Research Laboratory, 2001 South Rock Road, Fort Pierce, FL 34945; and third and fourth authors: Citrus Research and Education Center, University of Florida, 700 Experiment Station Road, Lake Alfred 33805.

Accepted for publication 28 December 2012.

\begin{abstract}
Hilf, M. E., Sims, K. R., Folimonova, S. Y., and Achor, D. S. 2013. Visualization of 'Candidatus Liberibacter asiaticus' cells in the vascular bundle of citrus seed coats with fluorescence in situ hybridization and transmission electron microscopy. Phytopathology 103:545-554.

'Candidatus Liberibacter asiaticus' is the bacterium implicated as a causal agent of the economically damaging disease of citrus called huanglongbing (HLB). Vertical transmission of the organism through seed to the seedling has not been demonstrated. Previous studies using real-time polymerase chain reaction assays indicated abundant bacterial $16 \mathrm{~S}$ rRNA sequences in seed coats of citrus seed but the presence of intact bacterial cells was not demonstrated. We used microscopy to verify that intact bacterial cells were present in citrus seed coats. Bacterial cells with the morphology and physical dimensions appropriate for ' $\mathrm{Ca}$. L. asiaticus' were seen in phloem sieve elements in the vascular bundle of

Fluorescence in situ hybridization (FISH) analyses utilizing probes complementary to the ' $\mathrm{Ca}$. L. asiaticus' $16 \mathrm{~S}$ rRNA gene revealed bacterial cells in the vascular tissue of intact seed coats of grapefruit and pummelo and in fragmented vascular bundles excised from grapefruit seed coats. The physical measurements and the morphology of individual bacterial cells were consistent with those ascribed in the literature to ' $\mathrm{Ca}$. $\mathrm{L}$. asiaticus'. No bacterial cells were observed in preparations of seed from fruit from noninfected trees. A small library of clones amplified from seed coats from a noninfected tree using degenerate primers targeting prokaryote 16S rRNA gene sequences contained no ' $\mathrm{Ca}$. L. asiaticus' sequences, whereas $95 \%$ of the sequences in a similar library from DNA from seed coats from an infected tree were identified as ' $\mathrm{Ca}$. L. asiaticus', providing molecular genetic corroboration that the bacterial cells observed by TEM and FISH in seed coats from infected trees were ' $\mathrm{Ca}$. L. asiaticus'.
\end{abstract} grapefruit seed coats using transmission electron microscopy (TEM).
'Candidatus Liberibacter asiaticus' is a phloem-colonizing Alphaproteobacteria (Rhizobiales; Rhizobiaceae) which is associated with the disease huanglongbing (HLB) (also known as greening), which occurs in many citrus-producing areas of the world $(3,19)$. It is one of three species of Liberibacter associated with economically damaging diseases of citrus and is found in many citrus-growing areas in southern and southeastern Asia, as well as in several major growing areas in North and South America, including Florida and Brazil $(3,19,37)$. HLB is an especially damaging disease because the establishment of the organism in a particular tree produces a chronic infection that leads to declining tree health, with subsequent declines in yield and fruit quality. Infection of individual trees in the field occurs by transmission of the bacterium by the Asian citrus psyllid (Diaphorina citri, Kuwayama) or by vegetative propagation of infected budwood $(3,19)$. Experimentally, dodder (Cuscuta sp.) has been used successfully to transfer Liberibacter spp. to periwinkle (Catharanthus rosea) (17), tomato (Solanum lycopersicum) (12), and tobacco (Nicotiana tabacum) (15), with observation of bacteria with transmission electron microscopy (TEM) in periwinkle, tobacco, and dodder itself (23).

There have been no clearly successful attempts to establish any of the three species of Liberibacter in a sustained culture $(9,34)$;

Corresponding author: M. E. Hilf; E-mail address: mark.hilf@ars.usda.gov

http://dx.doi.org/10.1094/PHYTO-09-12-0226-R

This article is in the public domain and not copyrightable. It may be freely reprinted with customary crediting of the source. The American Phytopathological Society, 2013. consequently, Koch's postulates have not been fulfilled and confirmation of ' $\mathrm{Ca}$. L. asiaticus' by growth in axenic culture is not possible. Currently, a diagnosis of the disease HLB is based upon confirmation of appropriate foliar symptoms in the presence of the appropriate psyllid vector, with corroborative evidence of the presence of the associated bacteria generated by conventional or quantitative real-time polymerase chain reaction (qPCR) (2529). Prior to the use of PCR to confirm the presence of ' $\mathrm{Ca}$. L. asiaticus' by detection of pathogen DNA in nucleic acid extracted from tissue, researchers used TEM to locate the bacterium in the phloem sieve tubes of symptomatic citrus tissue, confirming the presence of the bacterium and providing information on the basic morphology of the bacterium $(17,18)$.

Psyllids and infected citrus budwood are the common means of distribution of the pathogen. A potential third means of dispersal of ' $C a$. L. asiaticus' is the movement of seed from infected trees. Seed do not show explicit symptoms of HLB but undeveloped seed found in fruit from infected trees have been described as "aborted" $(3,19)$, although it is not clear if this poor development is a symptom of direct infection of the seed or is part of a more general negative effect on development of the fruit due to infection and symptom development in the tree. In recently published studies on seed transmission, researchers observed seedlings for symptoms and used conventional and qPCR to detect bacterial DNA in seedlings germinated from seed from infected trees and found no evidence that seedlings were infected $(1,20,22,24,35)$. In some of these studies, PCR assays detected small amounts of ' $\mathrm{Ca}$. L. asiaticus' DNA in a small number of germinated seedlings but subsequent samplings of these seedlings detected no bacterial 
DNA, suggesting that, if bacteria initially were able to colonize tissues in the seedlings, they did not establish a persistent infection $(1,20)$.

A study on the distribution of " $\mathrm{Ca}$. L. asiaticus' in planta (36) as well as our recent study on seed transmission of ' $\mathrm{Ca}$. L. asiaticus' (24) demonstrated that ' $C a$. L. asiaticus' DNA was detected frequently in the seed coats of healthy-appearing, viable seed from infected sweet orange and grapefruit trees, although no infected seedlings germinated from these seed. In a different study, Folimonova et al. (14) demonstrated that qPCR assays generated equivalent cycle threshold values from DNA extracted from older HLB-symptomatic foliar tissue and from younger asymptomatic foliar tissue, yet TEM revealed intact bacterial cells in only the younger, asymptomatic tissue, suggesting that, in the older symptomatic tissue, the qPCR assay detected pathogen DNA no longer associated with intact cells.

This finding by Folimonova et al. (14) raised the possibility that the pathogen DNA we detected in seed coats may not have been associated with intact bacterial cells which would, at least in part, provide an explanation of why no seed transmission has been observed. Despite a lack of experimental evidence of seed transmission, current federal regulations prohibit movement of citrus material, including seed, from areas where both the vector and the pathogen are present (7). Because successful seed transmission would require the presence of intact, viable bacterial cells in the seed, we wanted to determine whether the " $\mathrm{Ca}$. L. asiaticus' DNA detected in seed coats in previous studies was derived from intact bacterial cells. In this current study, we confirm the presence of bacterial cells in phloem sieve tubes in the citrus seed coat with TEM, and we also present observations of ' $\mathrm{Ca}$. L. asiaticus' with light microscopy with the application of fluorescence in situ hybridization (FISH) (10) to detect ' $\mathrm{Ca}$. L. asiaticus' $16 \mathrm{~S}$ rRNA. In addition, we prepared a small library using degenerate primers designed to amplify a portion of the 16S rRNA gene sequence from a wide taxonomic range of prokaryotes which provided corroborative molecular genetic data, indicating that the bacteria observed in the microscopy studies were ' $\mathrm{Ca}$. L. asiaticus'.

\section{MATERIALS AND METHODS}

Source of seed. Seed of 'Conners' and of 'Inman' grapefruit (Citrus paradisi Macf.), two closely related, noncommercial, seedy white-fleshed grapefruit, and of 'Liane' pummelo (C. grandis (L.) Osbeck) were extracted from fruit harvested from HLB-symptomatic trees maintained on the United States Horticultural Research Laboratory farm in Fort Pierce, FL. The infected status of these trees was verified by qPCR analysis of foliar samples, as described (24). The trees were planted pathogen free in 1999 and likely were infected with ' $C a$. L. asiaticus' by psyllids some time thereafter; the official identification of the HLB disease and verification of the presence of the bacterium in Florida were not made until 2005 (21) but the initial time of introduction of the organism into Florida is unknown. All seed used as negative controls for these studies were from trees at the United States Department of Agriculture-Agricultural Research Service A. H. Whitmore Farm, Lake County, FL. Seed from infected trees were collected in summer when fruit and seed were immature (fruit are not harvestable and seed will not germinate and develop if planted), and in late fall when both fruit and seed were mature (fruit is of harvestable size and quality and seed will germinate and develop if planted).

Tissue preparation and FISH. Aqueous solutions used in this study were autoclaved or filter sterilized as appropriate prior to use. Whole seed or seed coats were fixed in $4 \%$ paraformaldehyde overnight at room temperature, dehydrated by two successive 1-h incubations in each of 70, 80, 95, and $100 \%$ ethanol, followed by incubation in CitriSolv (Fisher Scientific, Pittsburgh, PA), then paraffin at $65^{\circ} \mathrm{C}$. Fixed, dehydrated samples were embedded in paraffin and a microtome was used to cut $10-\mu \mathrm{m}$-thick sections which were incubated in CitriSolv to remove the paraffin and rehydrated by two successive 10-min incubations in each of 100 , 95,80 , and $70 \%$ ethanol, then air dried.

For FISH analysis, seed coat vascular bundles were excised from seed coats, chopped with a scalpel on a microscope slide in sterile $15 \%$ sucrose in phosphate-buffered saline (PBS) $(0.003 \mathrm{M}$ $\mathrm{KCl}, 0.14 \mathrm{M} \mathrm{NaCl}, 0.005 \mathrm{M} \mathrm{Na}_{2} \mathrm{HPO}_{4}$, and $0.0018 \mathrm{M} \mathrm{KH}_{2} \mathrm{PO}_{4}$, $\mathrm{pH}$ 7.4), and fixed as described above. After fixation, these samples were not embedded in paraffin but were processed for hybridization as described below.

Samples subjected to analysis by FISH were fixed in place on a glass microscope slide in $4 \%$ paraformaldehyde for $4 \mathrm{~h}$ to overnight at $4{ }^{\circ} \mathrm{C}$, washed twice with PBS, and air dried. Fixed tissues were made permeable by successive incubations with lysozyme $(0.5 \mathrm{mg} / \mathrm{ml})$ in buffer $(100 \mathrm{mM}$ Tris- $\mathrm{HCl}$ and $5 \mathrm{mM}$ EDTA, $\mathrm{pH}$ 8.2) at room temperature for $30 \mathrm{~min}$ followed by incubation with Proteinase $\mathrm{K}(0.1 \mu \mathrm{g} / \mathrm{ml})$ in PBS at room temperature for $10 \mathrm{~min}$. After each treatment, samples were washed two to three times with PBS. For hybridization, labeled probes diluted to $1 \mathrm{ng} / \mu \mathrm{l}$ in hybridization buffer $(0.9 \mathrm{M} \mathrm{NaCl}, 20 \mathrm{mM}$ Tris- $\mathrm{HCl}, 0.01 \%$ sodium dodecyl sulfate, and $40 \%$ formamide) were applied to fixed, permeabilized samples and incubated in the dark at $46^{\circ} \mathrm{C}$ for $2.5 \mathrm{~h}$ to overnight in a StatSpin ThermoBrite (IRIS International Inc., Westwood, MA). Following hybridization, excess probe was removed by washing successively for $15 \mathrm{~min}$ in buffer (0.9 M NaCl and $0.02 \mathrm{M}$ Tris- $\mathrm{HCl}, \mathrm{pH} 7.5)$ at $56^{\circ} \mathrm{C}$ and room temperature, followed by a rinse in distilled water; slides were then air dried. Prolong Gold anti-fade (Life Technologies, Carlsbad, CA) was applied to slides to which coverslips were added, followed by incubation at $40^{\circ} \mathrm{C}$ on a slide warmer overnight.

Oligonucleotides complementary to the ' $\mathrm{Ca}$. L. asiaticus' $16 \mathrm{~S}$ rRNA were selected for FISH based on published results of a study to determine which regions of the Escherichia coli $16 \mathrm{~S}$ rRNA were most accessible for binding labeled oligonucleotides (16). The oligonucleotides were designed based on the sequence of the ' $\mathrm{Ca}$. L. asiaticus' $16 \mathrm{~S}$ rRNA gene at coordinates 416,812 to 418,322 in the designated negative strand of GenBank accession NC012985 (11), and were Las 406 (5'-CATTATCTTCTCCG GCG-3'), bases 417,902 to 417,918 ; Las 483 (5'-CCGAAC AACGCTCGCCCCC-3'), bases 417,823 to 417,841 ; and Las 815 (5'-CCCCAGGCGGAGTGCTTA-3'), bases 417,492 to 417,509 . Oligonucleotide probes were synthesized with the fluorescent label Alexa Fluor 594 attached to the $5^{\prime}$ end (Invitrogen Corp., Carlsbad, CA).

FISH results were recorded with 35-mm Kodak ULTRAMAX ISO 400 film using an Olympus AX70 Provis microscope equipped with Olympus PM-C35DX cameras, which were used on the automatic setting.

TEM. Seed were prepared for TEM using a routine fixation and staining protocol, as described (14). Fixed and stained sections were viewed with a Morgagni 268 transmission electron microscope (FEI Co., The Netherlands).

Degenerate primer mediated PCR, cloning, and sequencing. Seed were surface sterilized, as described (24). Seed coats were peeled from seed of Conners grapefruit and pulverized in AP1 buffer (Qiagen, Valencia, CA) in a 2.0-ml microcentrifuge tube using a Mini-Beadbeater (Biospec Products Inc., Bartlesville, $\mathrm{OK})$. DNA was extracted from pulverized tissue with the DNeasy Plant Mini Kit (Qiagen). PCR amplification of the prokaryotic $16 \mathrm{~S}$ rRNA gene sequence from the seed coat DNA was performed with the primers 799f (5'-AACMGGATTAGATACCCKG-3') (5) and 1492-rm (5'-GNTACCTTGTTACGACTT-3') (31), which were designed to amplify $16 \mathrm{~S}$ rRNA gene sequences from a broad taxonomic range of prokaryotes. The PCR cycling parameters were $94^{\circ} \mathrm{C}$ for $60 \mathrm{~s}$; followed by 30 cycles of $94^{\circ} \mathrm{C}$ for $30 \mathrm{~s}, 50^{\circ} \mathrm{C}$ for $60 \mathrm{~s}$, and $72^{\circ} \mathrm{C}$ for $60 \mathrm{~s}$; and 1 cycle of $72^{\circ} \mathrm{C}$ for $10 \mathrm{~min}$. Amplified DNAs were separated by agarose gel electrophoresis, 
the appropriately sized DNA (735 bp) was excised from a $1.5 \%$ agarose gel and extracted from the agarose with the QIAquick PCR Purification Kit (Qiagen), and $2 \mu \mathrm{l}$ of this DNA was amplified a second time with the same primers and cycling parameters. This 735-bp band was purified from agarose and the DNA cloned by standard methods. Sequencing of cloned DNA was with an Applied Biosystems 3730 model sequencer.

\section{RESULTS}

TEM of seed coats. In all cases, seed coats were removed from seed prior to fixation for either light or electron microscopy. A typical seed coat half is shown in Figure 1, with the inner and outer seed coats, the seed coat vascular bundle, and the chalazal end of the seed indicated. Because ' $\mathrm{Ca}$. L. asiaticus' is a phloemcolonizing pathogen $(3,19)$, the phloem sieve tubes in the seed coat vascular bundle were seen as the likely locations of bacteria in the seed coat. From fruit collected in July 2010, 10 seed were analyzed and bacteria were seen in sections of 6 or 7 seed coats. Additional seed sampled in September 2010 showed intact and degraded bacteria; analysis of additional seed sampled from fruit collected in the period of April to August 2011 showed intact bacteria in $100 \%$ of samples (D. S. Achor, personal communication).

TEM evaluation of thin sections of Conners seed coats collected in July 2010 from immature, nonharvestable fruit revealed bacteria in phloem sieve elements of the seed coat vascular bundle (Fig. 2A and B), which showed pleiomorphic round and elongated bacilliform-like shapes characteristic of ' $\mathrm{Ca}$. L. asiaticus'. These bacteria are typical of what was observed for additional seed coat samples. Bacilliform cells which were similar to those seen in Figure 2A were measured from five sections and the diameters were 0.14 to $0.26 \mu \mathrm{m}$, values within the ranges reported for these shapes viewed in earlier studies $(14,17,23)$. In addition to the easily identified bacilliform shapes, there were many round bacterial cells, sometimes in great numbers (Fig. 2B), which appeared too large to be transverse sections of the bacilliform shapes and which had a size of 0.30 to $0.99 \mu \mathrm{m}$. These rounder, larger shapes and the range of diameters also were similar to those of cells seen in citrus, dodder, and periwinkle in previous studies $(14,17,23)$. During a study on seed transmission, the seed coat was the seed tissue in which bacterial DNA was most frequently if not exclusively detected (24), and these micrographs indicate that intact ' $\mathrm{Ca}$. L. asiaticus' cells that are shaped similarly to those seen in previous studies are present in the sieve elements in the seed coat vascular bundle.

FISH of seed coats and isolated seed coat vascular bundles from infected trees. Intact seed coats and excised, diced seed coat vascular bundles were fixed for and subjected to analysis by FISH, as outlined in Materials and Methods.

In a section of a Conners grapefruit seed coat from a fruit collected in July 2011, intense fluorescence (indicated by the larger asterisks) is seen adjacent to xylem vessels (X) (Fig. 3A and B). The fluorescence seen in this cross-section is similar to that seen in sections from vascular bundles from other seed coats sampled at other times of the year (data not presented). The location of the fluorescence near the xylem vessels suggests that it is from adjacent phloem sieve tubes, consistent with the literature describing this bacterium as colonizing and being limited to the phloem. The smaller asterisks (Fig. 3A) indicate fluorescence from what, based on their shape and on their size relative to the scale bar, may be individual bacteria.

Areas within sections from a seed coat taken in December 2010 from a mature Liane pummelo fruit also showed intense fluorescence (Fig. 4). Results depicted in Figure 4 are representative of those seen for the analysis of vascular bundles from different samples (data not presented). A $\times 40$ magnification of one area of a section of the Liane seed coat (Fig. 4A, smaller inset) shows elongated regions of intense fluorescence, as would be expected for hybridization of the probes to bacteria within phloem sieve tubes. The circled area in Figure 4A is seen enlarged in Figure 4B and the single and double asterisks indicate the same positions in both panels. Figure 4B is a $\times 100$ magnification of the area bounded by the circle in the smaller inset panel (Fig. 4A), and the higher magnification shows more clearly individual fluorescing bacteria (marked by filled circles) associated with the areas of intense fluorescence.

A $\times 40$ magnification of an adjacent region of the same section seed coat as seen in Figure 4A is shown in Figure 4C. The asterisks indicate the same approximate positions in Figure $4 \mathrm{C}$ and D. Figure 4D is a $\times 100$ magnification of the area in Figure $4 \mathrm{C}$ but it also presents a slightly different focal plane. This different focal plane shows that the indistinct areas of bright fluorescence indicated by the single and double asterisks in the inset (Fig. 4C) appear to be masses of individual bacterial cells (some of which are indicated by filled circles) which are revealed by the higher magnification (Fig. 4D). The bounded, tube-like character of the areas of fluorescence seen in both panels is expected for bacteria which are contained within phloem sieve tubes.

In addition to analyzing sections from intact seed coats, the vascular bundles from the seed coats of Inman grapefruit seed collected in December 2010 were excised, pulverized to fragment the vascular bundles, fixed on a glass slide, and analyzed by FISH.

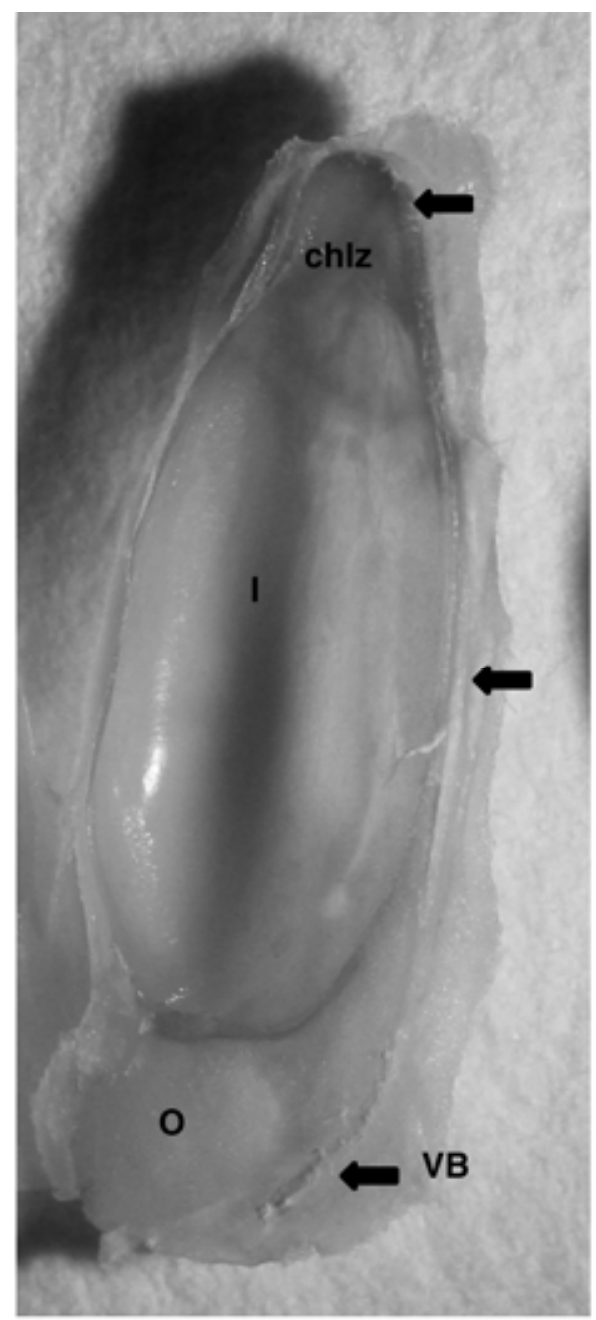

Fig. 1. One-half of a seed coat peeled from a seed of 'Conners' grapefruit. Arrows indicate the seed coat vascular bundle in the outer seed coat. The darker inner seed coat and the darker chalazal end of the seed also are shown. VB, vascular bundle; O, outer seed coat; I, inner seed coat; Chlz, chalazal end of the seed coat. 
Bacterial cells released from a sample of three vascular bundles are shown in Figure 5A. Asterisks indicate larger contiguous and smaller scattered patches of intense fluorescence emanating from fragments of the vascular bundle. Groups of individual bacteria adjacent to larger areas of intense fluorescence are indicated by asterisks in Figure 5B and C; the cells appear to have been released from sieve tubes due to the pulverization of the tissue.

Measurements of the apparent individual bacterial cells seen in Figures 4 and 5 gave a range of transverse lengths of 1.7 to $2.3 \mu \mathrm{m}$ and a mean diameter of $0.3 \mu \mathrm{m}$. This range of measurements for the transverse lengths is smaller than the values of 2.6 to $6.3 \mu \mathrm{m}$ reported for the bacilliform shapes from dodder tissues analyzed by TEM from a recent study of ' $\mathrm{Ca}$. L. asiaticus' in dodder (23). The range of diameters of the bacilliform shapes seen with TEM in this study was 0.14 to $0.26 \mu \mathrm{m}$, which is smaller than the $0.3 \mu \mathrm{m}$ calculated for the cells seen with FISH in Figures 4 and 5 but closer to the lower end of the range of 0.33 to $0.66 \mu \mathrm{m}$ found for bacterial cells by TEM in dodder (23).
To assess the type and degree of fluorescence from hybridization to noninfected tissue, fixed sections of seed coats derived from seed from fruit collected from trees in which ' $\mathrm{Ca}$. L. asiaticus' was not detected were used as negative controls for FISH.

No defined, elongated areas of fluorescence emanating from phloem sieve tubes were seen in seed coats removed from Conners seed which came from the noninfected trees, nor were individual bacteria seen in these preparations (data not shown). Pictures of these samples taken with longer exposure times ( $>20 \mathrm{~s})$ did show diffuse background autofluorescence but this was dissimilar to and distinguishable from the more specific fluorescence seen in the shorter exposures needed for the positive samples.

Analysis of prokaryote 16S rRNA gene sequences amplified from DNA extracted from citrus seed coats. As indicated above, taxonomically diverse bacteria have been described as constituents of citrus tissue, potentially present in the phloem $(11,32)$. To determine what bacteria in addition to ' $\mathrm{Ca}$. L. asiaticus' may be present in seed coat tissues from infected trees as

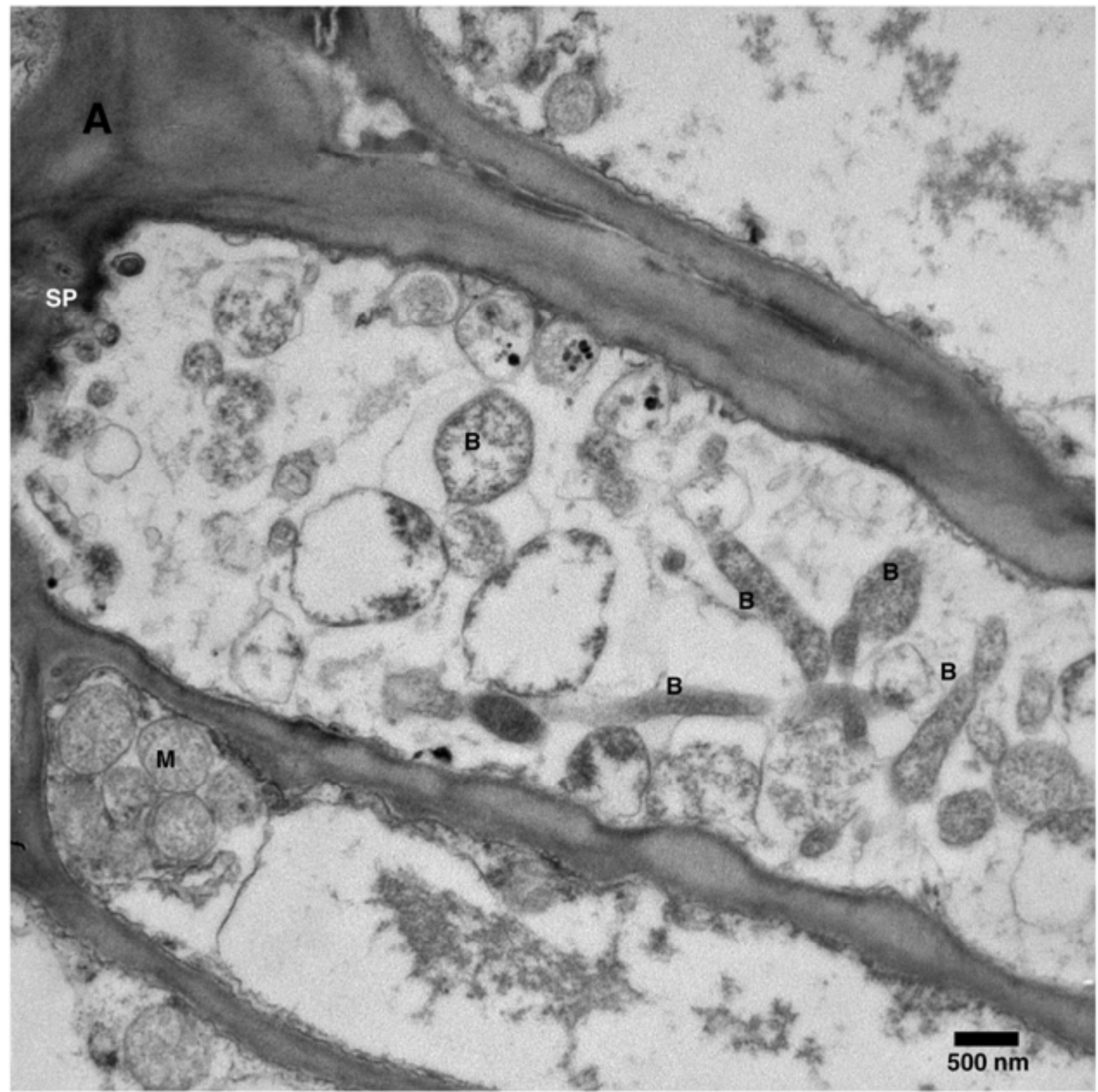

(Continued on next page)

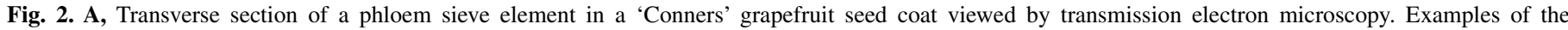

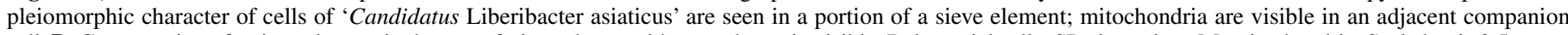
cell. B, Cross-section of a sieve element in the grapefruit seed coat with many bacteria visible. B, bacterial cells; SP, sieve plate; M, mitochondria. Scale bar is $0.5 \mu$ m. 
well as from noninfected trees, we used degenerate prokaryotic $16 \mathrm{~S}$ rRNA gene primers $(5,31)$ to amplify from extracts of seed coat DNA to generate sequences representing the bacterial population in these extracts. Two successive rounds of amplification were conducted to insure adequate amounts of DNA for cloning. The initial round of amplification produced equivalent amounts of the expected 1,040-bp host mitochondrial 16S rRNA gene fragment from DNA from both noninfected (lanes 1 to 3 ) and infected (lanes 4 to 6) seed coats (Fig. 6A). The desired 735-bp prokaryote $16 \mathrm{~S}$ rRNA gene fragment was seen only in reactions with DNA from seed coats from the infected source tree (lanes 4 to 6). No products were amplified from reactions which did not include template DNA (Fig. 6A, lanes 7 to 9). Gel pieces containing the 735-bp DNA fragment were cut from lanes 4 to 6 and from the corresponding positions in lanes 1 to 3 (Fig. 6A). The DNA purified from the gel pieces was used in a second round of amplification with the same primers and cycling parameters. Lanes 1 to 5 (Fig. 6B) show second-round amplification products from DNA extracted from lanes 1 to 3 from Figure 6A and, even though a 735-bp DNA was not visible after one round of amplification, a band of this size is easily seen after the second round. Some host mitochondrial product was co-purified and co-amplified. Lanes 6 to 10 (Fig. 6B) show the desired 735-bp DNA product amplified from the DNA extracted from lanes 4 to 6 (Fig. 6A). The 735-bp DNA fragments from gel lanes 1 to 5 and 6 to 10 (Fig. 6B) were purified and used to construct small libraries for analysis of the population of prokaryotes present in these seed coats.

In all, 192 clones derived from DNA from seed coats from the infected and noninfected sources each were submitted for analysis. For the noninfected source, 171 robust sequences were obtained from the library, and the analysis using BLAST indicated that none were identifiably similar to ' $\mathrm{Ca}$. L. asiaticus' (Table 1). The majority of these clones (135 of 171) were most similar to a range of non-cultivable bacteria and the sweet orange $(C$. sinensis) chloroplast $16 \mathrm{~S}$ rRNA gene sequence. A lesser number (36 of 171) were most similar to various species of a range of recognized bacterial genera (Table 1).

In total, 173 robust sequences were obtained for clones derived from the DNA from the infected seed coats, and a BLAST analysis indicated that 164 of $173(95 \%)$ were most similar to 'Ca. L. asiaticus' whereas only 9 of $173(5 \%)$ were not recognized as ' $\mathrm{Ca}$. L. asiaticus'.

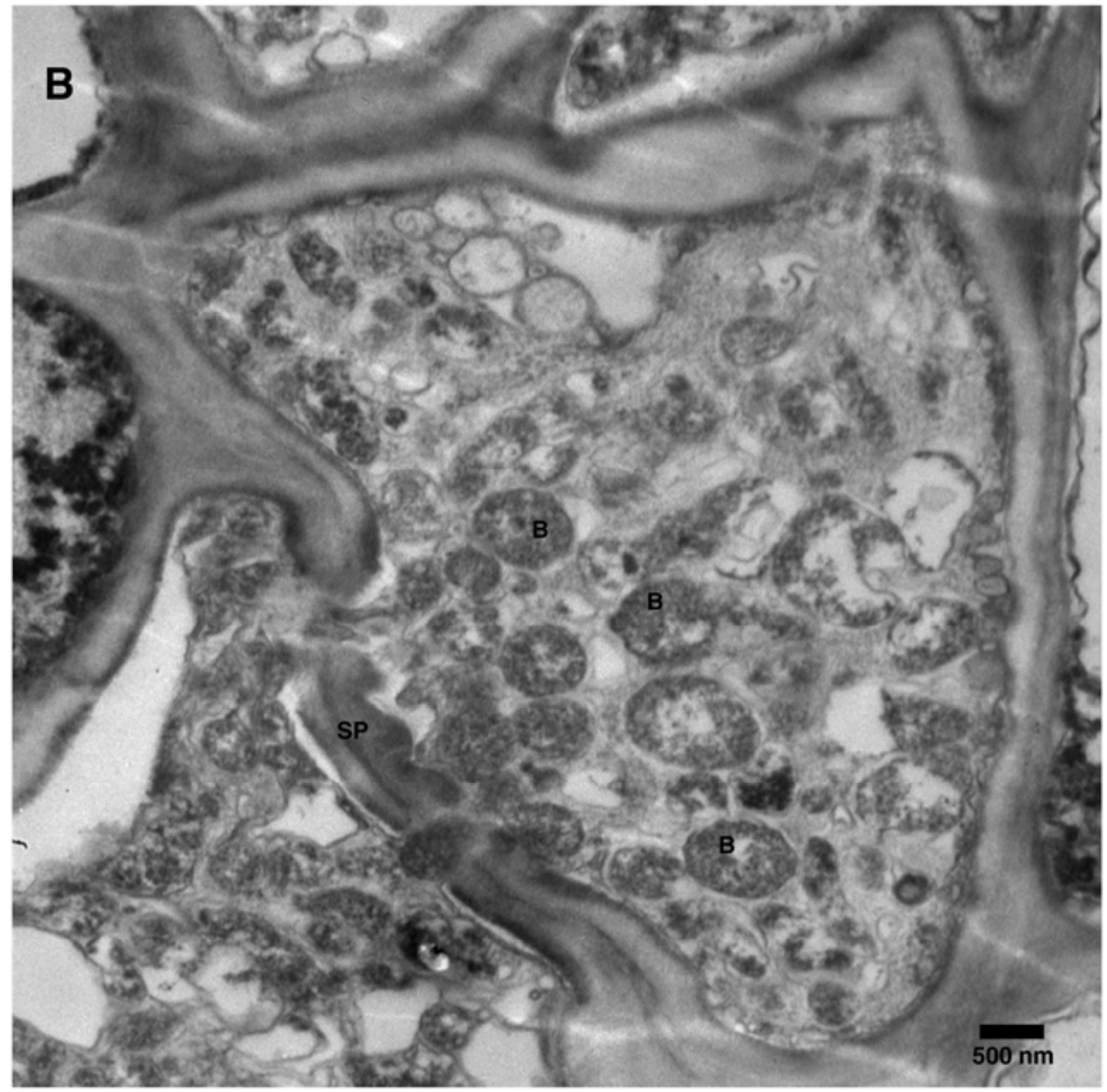

Fig. 2. (Continued from previous page) 
These sequence data and the lack of specific hybridization in FISH to seed coat tissues from the noninfected source suggest that the bacteria observed with FISH in extracts from and in sections of seed coats from an infected source are ' $\mathrm{Ca}$. L. asiaticus'.

\section{DISCUSSION}

In this work, we have demonstrated the presence of intact cells of the bacterium ' $\mathrm{Ca}$. L. asiaticus' in phloem sieve tubes in the seed coats of citrus seed using TEM and FISH. In our and other studies on the occurrence of seed transmission of this bacterium $(1,20,22,24,35)$, the presence of the pathogen in germinated seedlings and in various tissues of the seed was implied from the detection of pathogen DNA; bacterial cells were never observed directly. The work of Folimonova and Achor (14) indicated that ' $C a$. L. asiaticus' DNA could be present in relatively large amounts in foliar tissue in the absence of intact bacterial cells, and it was unclear whether this also was the case with pathogen DNA detected in seed $(20,24)$. As a pathway for dissemination of the pathogen, seed transmission is a concern only if intact, viable bacteria are found in the seed; therefore, this work was conducted to confirm that bacterial cells are present. The results presented in this study are the first direct evidence that intact bacteria are present in any tissue of the citrus seed, suggesting that the pathogen DNA detected in seed coats in previous studies is derived from bacterial cells. These data suggest that the reported lack of transmission of the organism via seed $(1,20,22,24,35)$ is not due to the absence of the organism in seed tissue.

In this study, the detection of bacteria in phloem tissues in the seed coat is consistent with the general perception from studies with foliar tissue that this organism colonizes phloem sieve elements exclusively $(3,19)$. The bacterial cells observed with both TEM and FISH had shapes and physical dimensions within the range reported in earlier TEM studies $(14,17,23)$. In their recently published article, Ammar et al. (2) used FISH to visualize 'Ca. L. asiaticus' cells in psyllid tissues as well as in sections of citrus foliar tissue, and the authors described seeing short, thin fluorescent rods 1 to $2 \mu \mathrm{m}$ long, measurements which are similar to the 1.7 to $2.3 \mu \mathrm{m}$ reported in this study. The authors also indicated that these cells were widely scattered and irregu- larly dispersed in sections of foliar tissue, whereas the amount of fluorescence observed in the seed coats and isolated vascular bundles in this study suggests that there is a greater abundance of bacteria in a given amount of seed coat tissue. This study also showed that, in addition to its application to detect ' $C a$. L. asiaticus' in thin tissue sections, as demonstrated for seed coats in this study and for foliar tissue samples by Ammar et al. (2), the FISH methodology was effective with vascular bundles which were dissected from seed coats and crudely crushed, releasing bacteria which were effectively detected by the assay. This use of nonsectioned tissue fragments should be applicable to other plant tissues enriched for the bacterium as a relatively quick assay to verify the presence of intact bacterial cells.

Even though the specificity of the probes used in the FISH assays could not be tested on a sample of a pure culture of the bacterium, the overwhelming predominance of ' $\mathrm{Ca}$. L. asiaticus' $16 \mathrm{~S}$ rRNA gene sequences in a library of clones derived using degenerate prokaryote $16 \mathrm{~S}$ rRNA gene primers provided genetic evidence that the bacterial cells observed by TEM and by FISH in the seed coat tissues were ' $\mathrm{Ca}$. L. asiaticus'.

The two documented modes of dissemination which are considered epidemiologically important in the movement of ' $\mathrm{Ca}$. L. asiaticus' from an infested to a noninfested area are movement of psyllid vectors harboring the bacteria and movement of infected citrus budwood $(3,19)$. A potential third mode of dissemination from infected trees is the dispersal of infected seed or the derived seedlings. However, none of the published studies documented that any infected seedlings grew from seed from infected trees $(1,20,22,24,35)$, even when qPCR assays detected large amounts of pathogen DNA in the seed coats, which were removed from individual seed and analyzed prior to germination of the seed (24).

Therefore, why does ' $\mathrm{Ca}$. L. asiaticus' accumulate in the vascular tissue in the seed coat if this does not lead to increased dissemination of the pathogen? It is possible that, upon colonization of the phloem in the main body of the plant, the bacteria follow the source to sink pathway that directs movement of photosynthate throughout the plant. Duan et al. (11) noted that flagellae have never been identified in published micrographs of 'Ca. L. asiaticus' cells; in addition, even though a nearly complete set of genes for flagellae biosynthesis were identified in the ge-
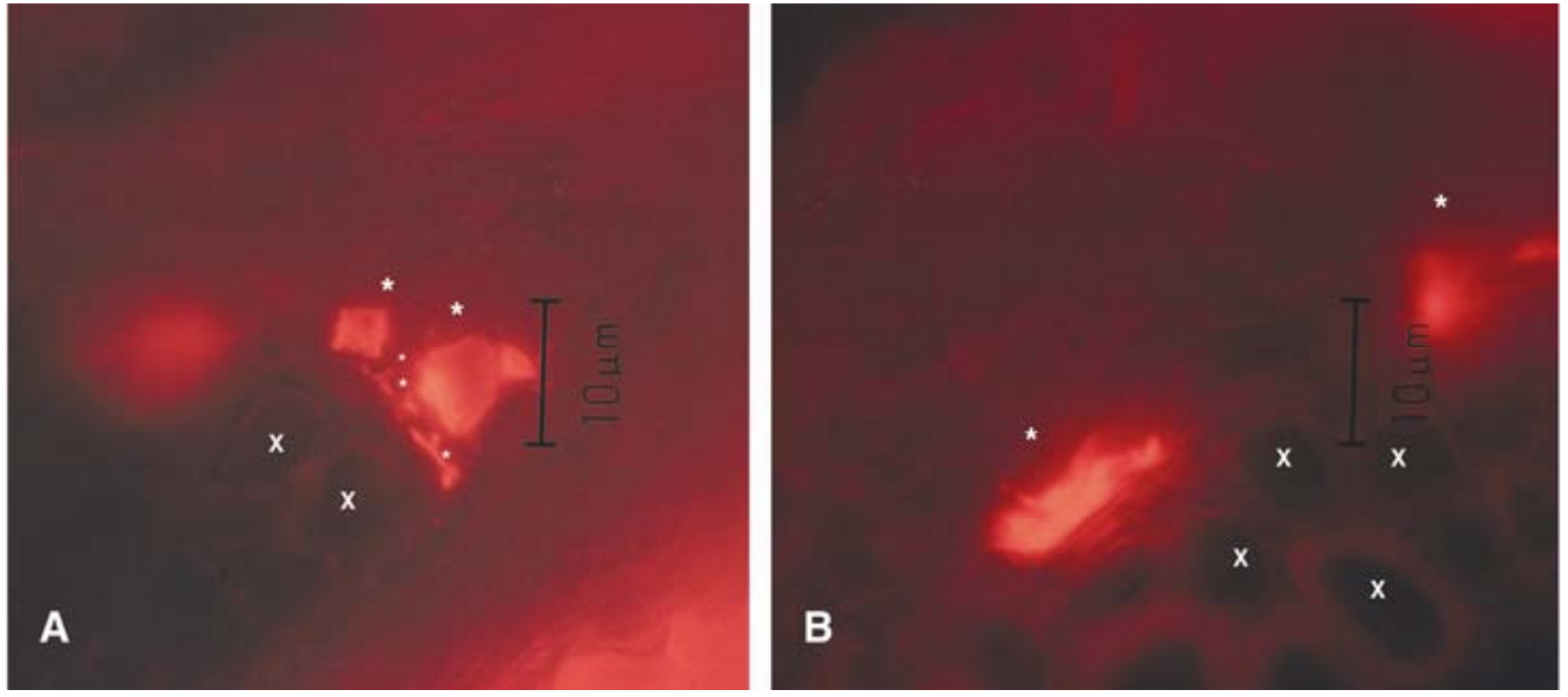

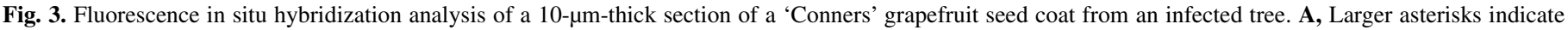

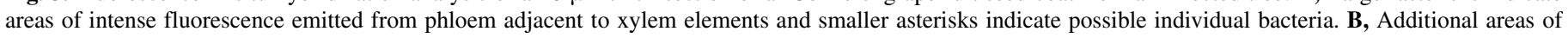
intense fluorescence from phloem adjacent to xylem vessels are marked by asterisks. X: xylem vessels. Scale bar is $10 \mu \mathrm{m}$. 

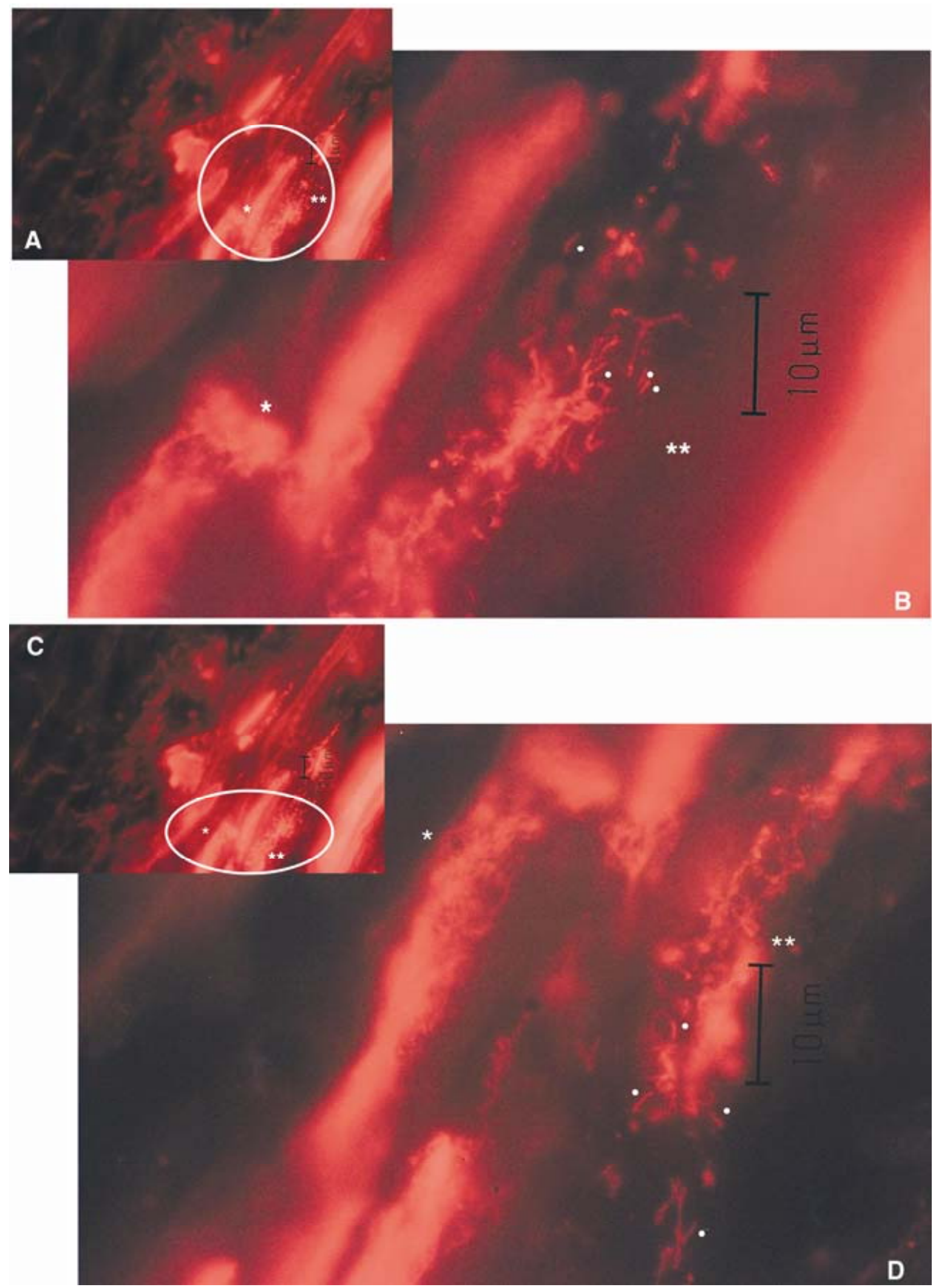

Fig. 4. Fluorescence in situ hybridization analysis of a section of a 'Liane' pummelo seed coat. A and C, Smaller insets show a larger field of view at $\times 40$ magnification, with the encircled area shown at a higher $\times 100$ magnification in B and D, respectively. Asterisks in A and C indicate the same approximate areas in $\mathrm{B}$ and $\mathrm{D}$, with the single asterisks indicating representative areas of intense fluorescence and the double asterisks indicating areas of fluorescence in which individual bacteria are observed. B and D, Individual bacteria are indicated by small, filled circles. Scale bar is $10 \mu \mathrm{m}$. 

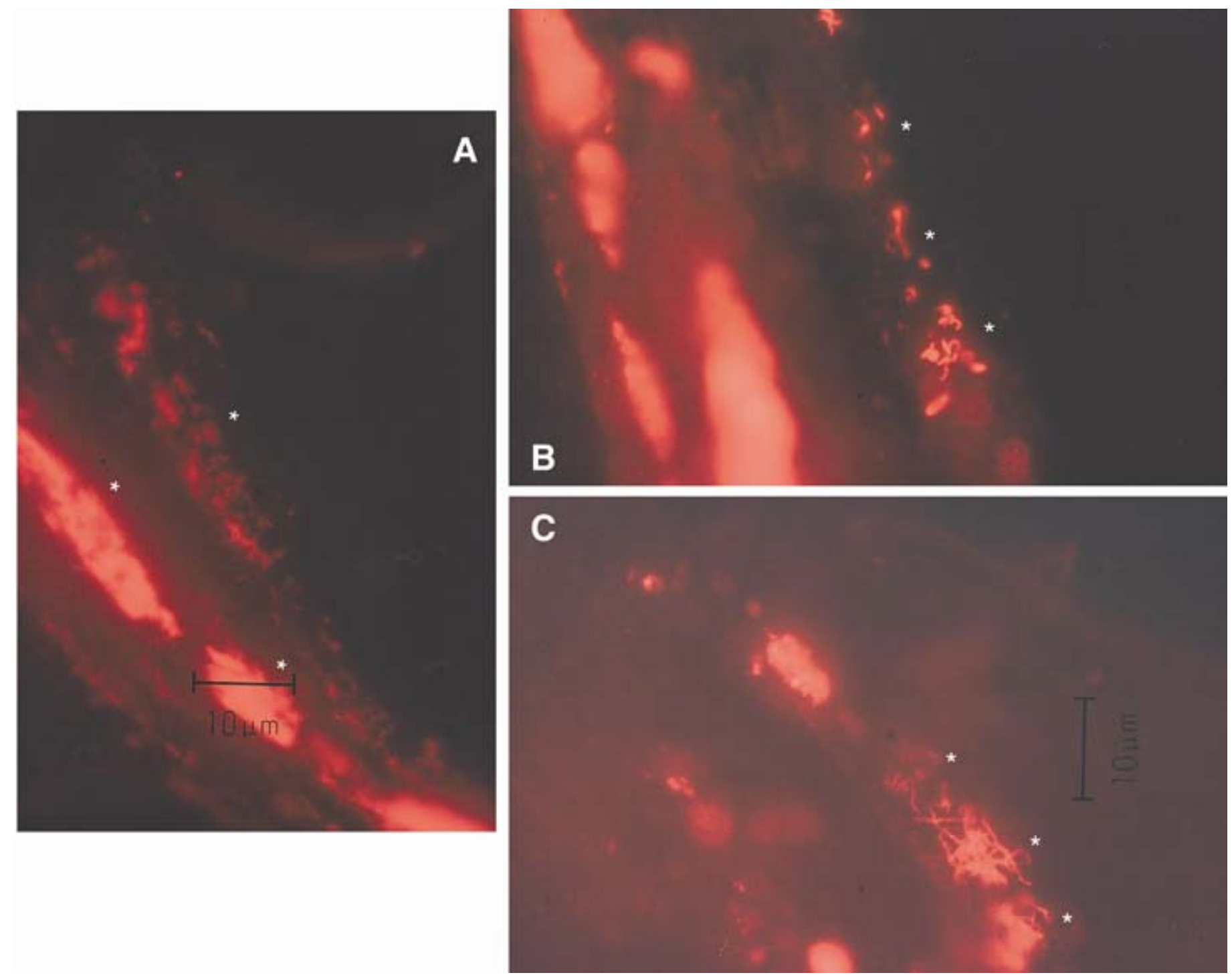

Fig. 5. Fluorescence in situ hybridization analysis of vascular bundles excised from the seed coats of 'Inman' grapefruit seed. A, Asterisks indicate areas of intense fluorescence emanating from vascular bundle fragments. B and C, Asterisks indicate groups of individual bacteria associated with vascular bundle fragments. Scale bar is $10 \mu \mathrm{m}$.

nome, several key genes were thought to be pseudogenes, suggesting that flagellae may not be synthesized. This suggests that movement of the bacteria in the phloem may be passive and, because developing seed represent tremendous sinks for photosynthate movement, bacteria may follow this path into the vascular tissue in the seed coat.

As an intracellular pathogen, the ' $\mathrm{Ca}$. L. asiaticus' genome, not surprisingly, has no genes identified with type III or type IV secretion systems or genes for cell-wall-degrading enzymes; in addition, the genes of the type II secretion pathway involved in excretion of extracellular enzymes are not present in the genome (11). Once established in the vascular tissue of the seed coat in the developing seed, the organism likely cannot proceed further, because there is no direct vascular connection between the seed coat and the developing embryo to allow movement of the bacteria out of the seed coat by this path, and the organism does not have the genetic arsenal needed to release itself from the phloem sieve tubes and colonize the embryo.

Faghihi et al. (13) found no seed transmission of "Candidatus Phytoplasma aurantifolia", another noncultivable, phloem-colonizing bacterium that is causally associated with the witches'broom disease of lime. Similar to what has been observed for ' $\mathrm{Ca}$. L. asiaticus', bacterial DNA was detected in seed coats but not in either the endosperm or in excised embryos from seed from infected, symptomatic trees. Phytoplasmas colonize plant phloem similarly to Liberibacter spp., and it has been suggested that seed transmission of phytoplasmas is not expected because of a lack of an appropriate vascular connection with the seed (6), an argument which has been made for ' $\mathrm{Ca}$. L. asiaticus' (1) based on the known anatomy of citrus seed (33). Interestingly, in one study, DNA of the coconut yellows phytoplasma was detected in embryos from coconut palms with lethal yellowing (8), and a recent study detected phytoplasma DNA in tomato, oilseed rape, and corn seedlings germinated from seed obtained from infected source plants (4); data which, in both studies, were seen as indicating possible seed transmission of the respective phytoplasmas. Therefore, it is possible that seed transmission can occur in the appropriate host. It should be noted, however, that, in both of these studies, only phytoplasma DNA was detected in the indicated plant tissues; no direct visualization of bacteria was reported, and the study on coconut lethal yellowing did not generate seedlings which could be tested further.

In contrast to the phloem-restricted Liberibacter spp. and phytoplasmas, $\mathrm{Li}$ et al. (30) demonstrated that the xylemrestricted bacterium Xylella fastidiosa, which causes the citrus disease citrus variegated chlorosis, was transmitted through citrus 

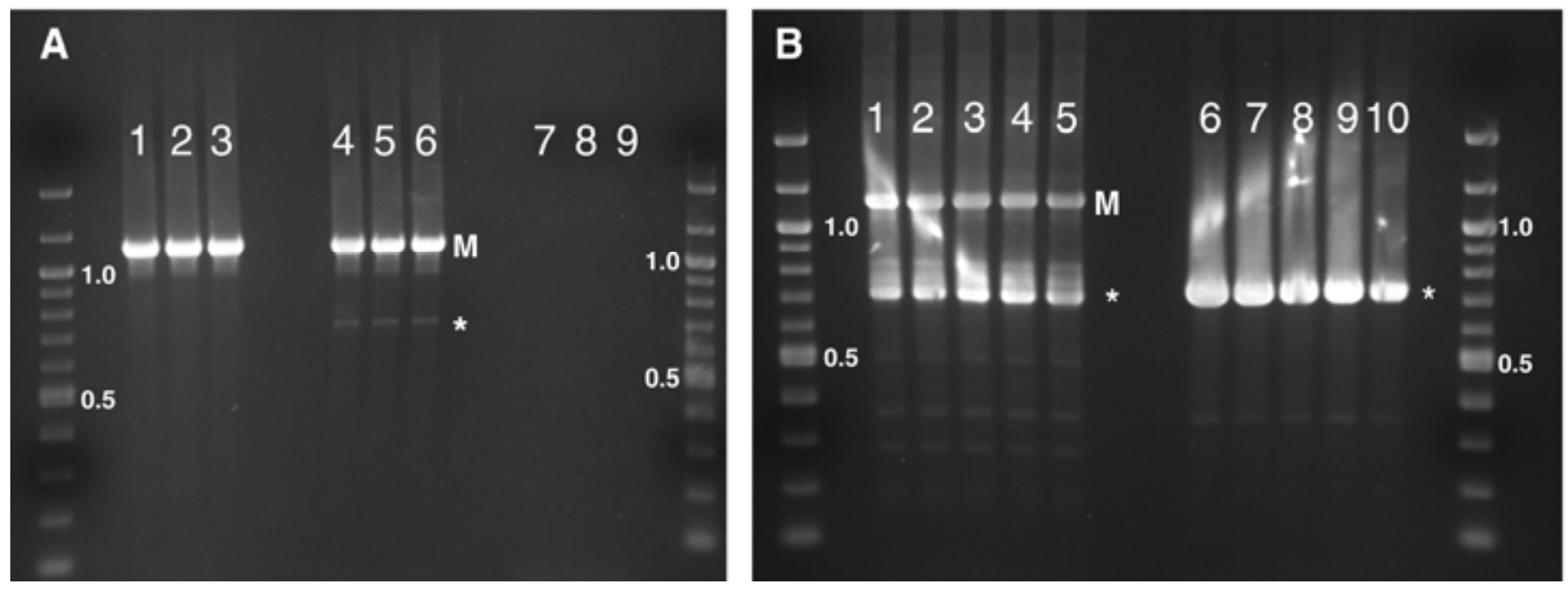

Fig. 6. Amplification of prokaryotic 16S rRNA gene sequences from seed coat DNA using degenerate primers. A, Results of the initial round of polymerase chain reaction. Lanes 1 to 3, DNAs amplified from seed coats from fruit from noninfected trees; lanes 4 to 6, amplified DNAs from seed coats from infected trees; and lanes 7 to 9 , products from no-template control reactions. The prokaryotic 16S rRNA gene fragment (lanes 4 to 6 ) or its expected position in the gel (lanes 1 to 3 ) is indicated by the asterisk (*). B, Results of the second round of amplification. Lanes 1 to 5, DNA generated from amplification of the gel-purified 16S rRNA gene fragment from the indicated position in lanes 1 to 3 in A; and lanes 6 to 10, DNA obtained from amplification of the gel-purified 16S rRNA gene fragment indicated in lanes 4 to 6 in A. Outermost lanes in both gels show 100-bp molecular size marker DNAs, with sizes indicated in kilobase pairs; M indicates the host mitochondrial DNA product.

TABLE 1. Results of an assessment of the microbial community in seed coats from infected and noninfected 'Conners' grapefruit trees by sequencing a fragment of the 16S rRNA gene amplified with degenerate primers

\begin{tabular}{lcc}
\hline Seed coat & Number of & \\
DNA source & sequences & Taxonomic affinity ${ }^{\mathrm{a}}$ \\
\hline Noninfected & $135 / 171$ & Various taxonomically unassigned, noncultivable bacteria and Citrus sinensis chloroplast 16S rRNA gene \\
& $36 / 171$ & Comamonas spp., Lactococcus spp., Ralstonia spp., Chryseobacterium spp., Isoptericola spp., Acinetobacter spp., \\
& & Staphylococcus spp., Geobacillus sp., Clostridium spp., Delftia spp. \\
Infected & $164 / 173$ & 'Candidatus Liberibacter asiaticus' \\
& $7 / 173$ & Various taxonomically unassigned, non-cultivable bacteria and Citrus sinensis chloroplast 16S rRNA gene \\
& $2 / 173$ & Pseudomonas spp. \\
\hline
\end{tabular}

${ }^{a}$ Based on the maximum score, degree of coverage, and sequence identity generated by the BLAST algorithm.

seed which then germinated infected seedlings. However, the genomes of Liberibacter spp. and phytoplasmas are much reduced compared with those of Xylella spp., and the former organisms lack many of the genes for the secretion pathways which may allow the latter to effectively colonize seed for transmission via this route $(39,41)$.

Even though the FISH analyses showed intact bacterial cells in the seed coat vascular bundle, their viability is unknown because the assay does not directly address this and there are no reliable culturing methods $(9,34)$ to assess the viability of the ' $C a$. L. asiaticus' cells found in the seed coats in this study. Trivedi et al. (40) speculated from studies which used ethidium monoazide in conjunction with qPCR that only 17 to $31 \%$ of ' $\mathrm{Ca}$. L. asiaticus' cells were viable in the samples of HLB-symptomatic tissue they studied. The release of individual bacteria from crushed vascular bundles as visualized by FISH suggests that the viability of these bacteria could be assessed using microscopy methods which determine cell viability based on differential fluorescence due to the status of membrane integrity (so called "live-dead" assays).

In general, citrus scion varieties are propagated clonally by vegetative grafting; therefore, potential seed transmission of ' $\mathrm{Ca}$. L. asiaticus' in these varieties would be unlikely as a route of dissemination. However, rootstocks used in commercial citrus production are produced from seed. A recommended practice utilized in the germination of citrus seed is the removal of the seed coat to speed germination (38). The current evidence suggests that the bacteria are likely exclusively in the seed coat; therefore, removal of the seed coat as part of a standard practice when germinating citrus seed removes an immediate source of inoculum, so that seed transmission would occur only if the bacteria are present in the cotyledons or the embryo. Overall, the collective data in several published studies which analyzed several thousand citrus seedlings showed no evidence for transmission through seed $(1,20,22,24,35)$.

Although we do not know why ' $\mathrm{Ca}$. L. asiaticus' colonizes seed coats, the data from this study clearly show that the pathogen DNA detected in seed coats in previous studies $(20,24)$ was derived from intact bacteria. Because the bacteria in these seed coats appear to be in near homogeneity, seed coats could be used as a significant source of relatively pure ' $\mathrm{Ca}$. L. asiaticus' cells for culturing and other analyses, provided they can be purified away from the host tissue in adequate numbers.

\section{ACKNOWLEDGMENTS}

Mention of a trade name, proprietary product, or specific equipment does not constitute a guarantee of warranty by the United States Department of Agriculture and does not imply approval to the exclusion of other products that may also be suitable. We thank A. Hughes for her technical assistance on this project.

\section{LITERATURE CITED}

1. Albrecht, U., and Bowman, K. D. 2009. 'Candidatus Liberibacter asiaticus' and huanglongbing effects on citrus seeds and seedlings. Hortic. Sci. 44:1967-1973.

2. Ammar, E.-D., Shatters, R. G., Jr., and Hall, D. G. 2011. Localization of 
'Candidatus Liberibacter asiaticus', associated with citrus huanglongbing disease, in its psyllid vector using fluorescence in situ hybridization. J. Phytopathol. 159:726-734.

3. Bové, J. M. 2006. Huanglongbing: A destructive, newly-emerging, century-old disease of citrus. J. Plant Pathol. 88:7-37.

4. Calari, E., Paltrinieri, S., Contaldo, N., Sakalieva, D., Mori, N., Duduk, B., and Bertaccini, A. 2011. Molecular evidence of phytoplasmas in winter oilseed rape, tomato and corn seedlings. Bull. Insectol. 64:S157158.

5. Chelius, M. K., and Triplett, E. W. 2001. The diversity of archaea and bacteria in association with the roots of Zea mays L. Microb. Ecol. 41:252-263.

6. Christensen, N. M., Axelsen, K. B., Nicolaisen, M., and Schulz, A. 2005. Phytoplasmas and their interactions with hosts. Trends Plant Sci. 10:526535.

7. "Citrus Greening and Asian Citrus Psyllid," Title 7 Code of Federal Regulations, Pt. 301. 2012 ed.

8. Cordova, I., Jones, P., Harrison, N. A., and Oropeza, C. 2003. In situ PCR detection of phytoplasma DNA in embryos from coconut palms with lethal yellowing disease. Mol. Plant Pathol. 4:99-108.

9. Davis, M. J., Mondal, S. N., Chen, H., Rogers, M. E., and Brlansky, R. H. 2008. Co-cultivation of 'Candidatus Liberibacter asiaticus' with actinobacteria from citrus with huanglongbing. Plant Dis. 92:1547-1550.

10. Delong, E. F., Wickham, G. S., and Pace, N. R. 1989. Phylogenetic strains: Ribosomal RNA-based probes for the identification of single cells. Science 243:1360-1363.

11. Duan, Y., Zhou, L., Hall, D. G., Li, W., Doddapaneni, H., Lin, H., Liu, L., Vahling, C. M., Gabriel, D. W., Williams, K. P., Dickerman, A., Sun, Y., and Gottwald, T. R. 2009. Complete genome sequence of citrus huanglongbing bacterium, 'Candidatus Liberibacter asiaticus' obtained through metagenomics. Mol. Plant-Microbe Interact. 22:1011-1020.

12. Duan, Y. P., Gottwald, T., Zhou, L. J., and Gabriel, D. W. 2008. First report of dodder transmission of 'Candidatus Liberibacter asiaticus' to tomato (Lycopersicum esculentum). Plant Dis. 92:831.

13. Faghihi, M. M., Bagheri, A. N., Bahrami, H. R., Hasanzadeh, H., and Rezazadeh, R. 2011. Witches'-broom disease of lime affects seed germination and seedling growth but is not seed transmissible. Plant Dis. 95:419-422.

14. Folimonova, S. Y., and Achor, D. S. 2010. Early events of citrus greening (huanglongbing) disease development at the ultrastructural level. Phytopathology 100:949-958.

15. Francischini, F. J. B., Oliveira, K. D. S., Astúa-Monge, G., Novelli, A., Lorenzino, R., Matiolli, C., Kemper, E., and Da Silva, A. C. R. 2007. First report on the transmission of 'Candidatus Liberibacter americanus' from citrus to Nicotiana tabacum cv. Xanthi. Plant Dis. 91:631.

16. Fuchs, B. M., Wallner, G., Beisker, W., Schwippl, I., Ludwig, W., and Amann, R. 1998. Flow cytometric analysis of the in situ accessibility of Escherichia coli $16 \mathrm{~S}$ rRNA for fluorescently labeled oligonucleotides probes. Appl. Environ. Microbiol. 64:4973-4982.

17. Garnier, M., and Bové, J. M. 1983. Transmission of the organism associated with citrus greening disease from sweet orange to periwinkle by dodder. 1983. Phytopathology 73:1358-1363.

18. Garnier, M., Danel, N., and Bové, J. M. 1984. Aetiology of citrus greening disease. Ann. Microbiol. (Inst. Pasteur) 135A:169-179.

19. Gottwald, T. R., da Graça, J. V., and Bassanezi, R. B. 2007. Citrus huanglongbing: The pathogen and its impact. Plant Health Progress. Online publication. doi:10.1094/PHP-2007-0906-01-RV

20. Graham, J., Johnson, E. G., Bright, D. B., and Irey, M. S. 2011. Lack of development of huanglongbing in seedlings from citrus seed. Proc. Fla. State Hortic. Soc. 124:65-68.

21. Halbert, S. 2005. The discovery of huanglongbing in Florida. Page 50 in: Proc. 2nd Int. Workshop Citrus Canker and Huanglongbing. Orlando, FL.

22. Hartung, J. S., Halbert, S. E., Pelz-Stelinksi, K., Brlansky, R. H., Chen, C., and Gmitter, F. G. 2010. Lack of evidence for transmission of 'Candidatus Liberibacter asiaticus' through citrus seed taken from affected fruit. Plant Dis. 94:1200-1205.

23. Hartung, J. S., Paul, C., Achor, D., and Bralansky, R. H. 2010. Colonization of dodder, Cuscuta indecora, by 'Candidatus Liberibacter asiaticus' and ' $\mathrm{Ca}$. Liberibacter americanus'. Phytopathology 100:756762.

24. Hilf, M. E. 2011. Colonization of citrus seed coats by 'Candidatus Liberibacter asiaticus': Implications for seed transmission of the bacterium. Phytopathology 101:1242-1250.

25. Hung, T. H., Wu, M. L., and Su, H. J. 1999. Development of a rapid method for the diagnosis of citrus greening disease using the polymerase chain reaction. J. Phytopathol. 147:599-604.

26. Jagoueix, S., Bové, J. M., and, Garnier, M. 1994. The phloem-limited bacterium of greening disease of citrus is a member of the $\alpha$ subdivision of the Proteobacteria. Int. J. Syst. Bacteriol. 44:379-386.

27. Jagoueix, S., Bové, J. M., and, Garnier, M. 1996. PCR detection of the two 'Candidatus Liberibacter' species associated with greening disease of citrus. Mol. Cell. Probes 10:43-50.

28. Li, W., Hartung, J., and Levy, L. 2006. Quantitative real-time PCR for detection and identification of 'Candidatus Liberibacter asiaticus' associated with citrus huanglongbing. J. Microbiol. Methods 66:104-115.

29. Li, W., Levy, L., and Hartung, J. 2009. Quantitative distribution of 'Candidatus Liberibacter asiaticus' in citrus plants with huanglongbing. Phytopathology 99:139-144.

30. Li, W.-B., Pria, W. D., Jr., Lacava, P. M., Qin, X., and Hartung, J. S. 2003. Presence of Xylella fastidiosa in sweet orange fruit and seeds and its transmission to seedlings. Phytopathology 93:953-958.

31. Roesch, L. F. W., Fulthorpe, R. R., Riva, A., Casella, G., Hardwin, A. K. M., Kent, A. D., Daroub, S. H., Camargo, F. A. O., Farmerie, W. G., and Triplett, E. W. 2007. Pyrosequencing enumerates and contrasts soil microbial diversity. ISME J. 1:283-290.

32. Sagaram, U. S., DeAngelis, K. M., Trivedi, P., Andersen, G. L., Lu, S.-E., and Wang, N. 2009. Bacterial diversity analysis of huanglongbing pathogen-infected citrus using PhyloChip arrays and 16S rRNA gene clone library sequencing. Appl. Environ. Microbiol. 75:1566-1574.

33. Schneider, H. 1968. The anatomy of citrus. Pages 1-85 in: The Citrus Industry, Vol. 2. W. Reuther, L. D. Batchelor, and H. J. Webber, eds. University of California, Berkeley.

34. Sechler, A., Schuenzel, E. L., Cooke, P., Donnua, S., Thaveechai, N., Postnikova, E., Stone, A. L., Schneider, W. L., Damsteegt, W. L., and Schaad, N. W. 2009. Cultivation of 'Candidatus Liberibacter asiaticus', 'Ca. L. africanus' and 'Ca. L. americanus' associated with huanglongbing. Phytopathology 99:480-486.

35. Shatters, R. G., Jr. 2008. Detection of 'Candidatus Liberibacter asiaticus' in citrus seedlings germinated from Florida seed. Page 198 in: Proc. Int. Res. Conf. Huanglongbing. T. R. Gottwald and J. H. Graham, eds. http:// www.plantmanagementnetwork.org/proceedings/irchlb/2008/

36. Tatineni, S., Sagaram, U. S., Gowda, S., Robertson, C. J., Dawson, W. O., Iwanami, T., and Wang, N. 2008. In planta distribution of 'Candidatus Liberibacter asiaticus' as revealed by polymerase chain reaction (PCR) and real-time PCR. Phytopathology 98:592-599.

37. Teixeira, D. C., Ayres, A. J., Kitajima, E. W., Tanaka, F. A. O., Danet, J. L., Jagoueix-Eveillard, S., Saillard, C., and Bové, J. 2005. First report of a Huanglongbing-like disease of citrus in São Paulo State, Brazil, and association of a new Liberibacter species, 'Candidatus Liberibacter americanus', with the disease. Plant Dis. 89:107.

38. Tolley, I. S., Cpag, O. A. M., and Tolley, N. C. 2001. Citrus seed-the base of an industry. Pages 42-48 in: Proc. 6th World Congr. Int. Soc. Citrus Nurserymen. L. C. Donadio, C. S. Moreira, and E. S. Stuchi, eds. Estação Experimental de Citricultura de Bebedouro, Ribiero Preto, São Paulo, Brazil

39. Tran-Nguyen, L. T., Kube, M., Schneider, B., Reinhardt, R., and Gibb, K. S. 2008. Comparative genome analysis of 'Candidatus Phytoplasma australiense' (subgroup tuf-Australia I; rp-A) and ' $\mathrm{Ca}$. Phytoplasma asteris' strains OY-M and AY-WB. J. Bacteriol. 190:3979-3991.

40. Trivedi, P., Sagaram, U. S., Kim, J.-S., Brlansky, R. H., Rogers, M. E., Stelinksi, L. L., Oswalt, C., and Wang, N. 2009. Quantification of viable 'Candidatus Liberibacter asiaticus' in hosts using quantitative PCR with the aid of ethidium monoazide. Eur. J. Plant Pathol. 124:553-563.

41. Van Sluys, M. A., de Oliveira, M. C., Monteiro-Vitorello, C. B., Miyaki, C. Y., Furlan, L. R., Camargo, L. E. A., da Silva, A. C. R., Moon, D. H., Takita, M. A., Lemos, E. G. M, Machado, M. A., Ferro, M. I. T., da Silva, F. R., Goldman, M. H. S., Goldman, G. H., Lemos, M. V. F., El-Dorry, H., Tsai, S. M., Carrer, H., Carraro, D. M., de Oliveira, R. C., Nunes, L. R., Sequeira, W. J., Coutinho, L. L., Kimura, E. T., Ferro, E. S., Harakava, R., Kuramae, E. E., Marino, C. L., Giglioti, E., Abreu, I. L., Alves, L. M. C., do Amaral, A .M., Baia, G. S., Blanco, S. R., Brito, M. S., Cannavan, F. S., Celestino, A. V., da Cunha, A. F., Fenille, R. C., Ferro, J. A., Formighieri, E. F., Kishi, L. T., Leoni, S. G., Oliveira, A. R., Rosa, V. E., Jr., Sassaki, F. T., Sena, J. A. D., de Souza, A. A., Truffi, D., Tsukumo, F., Yanai, G. M., Zaros, L. G., Civerolo, E. L., Simpson, A. J. G., Almeida, N. F., Jr., Setubal, J. C., and Kitajima, J. P. 2003. Comparative analyses of the complete genome sequences of Pierce's disease and citrus variegated chlorosis strains of Xylella fastidiosa. J. Bacteriol. 185:1018-1026. 